\title{
MEMBUAT SISTEM INFORMASI PENJUALAN PADA COUNTER JHON DENGAN MENGGUNAKAN BORLAND DELPHI
}

\author{
CHARZON \\ 785567896 \\ University Of Mitra Indonesia \\ charzon.student@umitra.ac.id
}

\begin{abstract}
Sistem informasi penting dalam dunia bisnis karena kinerjanya dapat memfasilitasi penjualan barang.

Jhon Mobile store adalah salah satu toko yang menjual berbagai jenis ponsel, aksesoris, Kartu SIM, pulsa, dan melayani layanan telepon seluler dalam pengolahan data barang masih menggunakan cek manual sehingga dapat memperumit stok yang masih ada atau barang yang telah terjual.

Pembuatan sistem informasi penjualan diharapkan memudahkan proses transaksi dan mendapatkan barang dengan cepat, tepat, dan akurat. Sistem informasi penjualan menggunakan aplikasi Borland Delphi 7.0. dalam penyimpanan data kapasitas besar, DBMS yang digunakan adalah Microsoft Office Access 2007.
\end{abstract}

Kata kunci: Sistem informasi penjualan, Borland Delphi 7.0, Microsoft office Access 2007. 


\section{A. INTRODUCTION}

\section{Pendahuluan}

Sistem informasi penjualan merupakan salah satu aplikasi yang digunakan untuk mempermudah pengguna dalam mengolah atau mengetahui data hasil penjualan. Sebagai alat bantu, komputer juga memiliki kelebihan, diantaranya kecepatan, keakuratan, serta efisiensi dalam pengolahan data bila dibandingkan dengan pengolahan data secara ma-nual.

Sistem informasi berbasis komputer yang baik senantiasa dapat mengatasi masalah-masalah yang terjadi serta dapat menghasilkan informasi secara cepat, tepat, dan akurat.

Kebutuhan sistem informasi pengolahan data penjualan mempunyai peran yang sangat penting untuk memperoleh data-data yang lebih akurat dan dapat mempermudah karyawan dalam melakukan pendataan barang sehingga dapat mencegah ke-salahan-kesalahan dalam transaksi penjualan dan dapat meningkatkan persaingan serta kepuasan pe-langgan. Saat ini dalam pengolahan data barang masih menggunakan cara manual hal ini dapat mem-persulit pengecekan stok barang yang masih ada maupun barang yang telah terjual.

\section{Rumusan Masalah}

Berdasarkan latar belakang yang telah diurai-kan sebelumnya, maka yang menjadi rumusan masa-lah adalah Bagaimana membuat sistem informasi penjualan pada Jhon Ponsel dengan menggu-nakan Borland Delphi 7.0

\section{Tujuan Penelitian}

Tujuan dari pembuatan tugas akhir ini antara
Lain:

- Membangun sistem informasi penjualan yang dapat mempermudah pengolahan data pada Jhon Ponsel.

- Membantu mengurangi kemungkinan kesalahan yang terjadi dalam transaksi penjualan.

\section{Metode Pengumpulan Data}

1 Metode Observasi, Mencatat kejadian atau peris-tiwa dengan menyaksikannya.

2 Metode Wawancara, Metode pengumpulan data dari hasil tanya-jawab/ mencari informasi lang-sung kepada pihak yang terkait tentang obyek yang diteliti.

\section{Metode Dokumentasi, Metode}

Pengumpulan data melalui dokumen tertulis maupun elektronik dari toko.

$4 \quad$ Metode Studi Pustaka, Metode pengumpulan data dengan cara mempelajari dan membaca buku-buku, literatur-literatur, catatan-catatan, dan laporan-laporan yang ada hubungannya dengan obyek penelitian.

\section{Landasan teori \\ Konsep Dasar Sistem}

Definisi sistem adalah kumpulan dari bagianbagian yang bekerja sama untuk mencapai tujuan yang sama atau sekumpulan objekobjek yang saling berelasi dan berinteraksi (Hanif Al Fatah, 2007)[1] Menurut Raymond Mcleod informasi adalah data yang telah diolah menjadi bentuk yang memiliki arti bagi si penerima dan bermanfaat bagi pengambilan keputusan saat ini atau mendatang.[2] Menurut (Sutarman , 2012) Informasi adalah sekum-pulan fakta (data) yang diorganisasikan dengan cara tertentu 
sehingga mereka mempunyai arti bagi si penerima Berdasarkan pendapat para ahli maka dapat disimpulkan bahwa informasi adalah hasil pengolahan data menjadi bentuk yang lebih berguna bagi penerimanya yang menggambarkan suatu kejadian-kejadian nyata dan dapat dipergunakan sebagai alat bantu untuk pengambilan keputusan. Komponen terpenting dari informasi adalah data. Antara data dan informasi terdapat perbedaan, data belum memiliki suatu nilai sedangkan informasi sudah memiliki nilai

\section{Definisi Sistem Informasi}

Sistem informasi adalah gabungan yang terorganisasi dari manusia, perangkat lunak, perang-kat keras, jaringan komunikasi dan sumber data dalam mengumpulkan, mengubah, dan menye-barkan informasi dalam organisasi. ${ }^{1}$ Sistem infor-masi adalah suatu sistem di dalam suatu organisasi yang mempertemukan kebutuhan pengolahan tran-saksi harian, mendukung operasi, bersifat manajerial dan kegiatan strategi dari suatu organisasi dan menyediakan pihak luar tertentu dengan laporanlaporan yang diperlukan. ${ }^{2}$

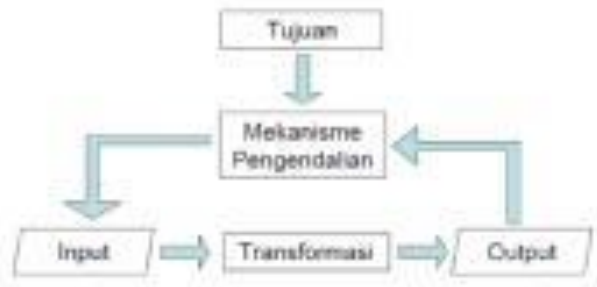

Gambar 1. Sistem Informasi Sumber : Raymond Mcleod, Goerge Schell, Sistem Informasi, 2001

Konsep Dasar Sistem Informasi Penjualan Penjualan adalah suatu kegiatan yang terpadu untuk mengembangkan rencanarencana strategis yang diarahkan pada usaha pemuasan kebutuhan dan keinginan pembeli, guna mendapatkan penjualan yang menghasilkan laba. Penjualan adalah sebuah usaha atau langkah konkrit yang dilakukan untuk memindahkan suatu produk, baik itu berupa barang ataupun jasa, dari produsen kepada konsumen sebagai sasarannya. Tujuan utama penjualan yaitu mendatangkan keuntungan atau laba dari produk ataupun barang yang dihasilkan produsennya dengan pengelolaan yang baik.

Sistem Informasi Penjualan adalah suatu sistem informasi yang mengorganisasikan serang-kaian prosedur dan metode yang dirancang untuk menghasilkan, menganalisa, menyebarkan dan memperoleh informasi guna mendukung pengambilan keputusan mengenai penjualan. Sistem informasi penjualan terdiri dari sekumpulan data informasi yang mendukung proses pemenuhan kebutuhan suatu organisasi yang bertanggung jawab untuk menyediakan informasi penjualan dan transaksi data dalam suatu kesatuan proses yang saling terkait antar

pembeli dan bersama-sama bertujuan untuk men-dapatkan keuntungan.

\section{Flowchart}

Flowchart adalah bagan (chart) yang menunjukan aliran (flow) didalam program atau prosedur sistem secara logika, digunakan terutama sebagai alat bantu komunikasi dan dokumentasi. Flowchart diawali dengan penerimaan input dan diakhiri dengan penampilan output. Sebuah flow-chart pada umumnya tidak menampilkan instruksi bahasa 
pemrograman, namun menetapkan konsep solusi dalam bahasa manusia ataupun notasi matematis

\section{UML (Unified Modeling Language)}

UML (Unified Modeling Language) adalah sebuah bahasa yang berdasarkan grafik atau gambar untuk memvisualisasikan, menspesifikasikan, mem-bangun dan pendokumentasian dari sebuah sistem pengembangan perangkat lunak berbasis objek (OOP). Menurut Widodo, 2011 UML adalah bahasa pemodelan standar yang memiliki sintak dan 40emantic. Menurut Nugroho, 2010 UML (Unified Modeling Language) adalah bahasa pemodelan untuk sistem atau perangkat lunak yang berparadigma (berorientasi objek). Pemodelan (modeling) sesungguhnya digunakan untuk penyederhanaan permasalahanpermasalahan yang kompleks sede-mikian rupa sehingga lebih mudah dipelajari dan dipahami. Berdasarkan pendapat yang dikemukakan di atas dapat ditarik kesimpulan bahwa UML adalah sebuah bahasa yang berdasarkan grafik atau gambar untuk menvisualisasikan, menspesifikasikan, me-mbangun dan pendokumentasian dari sebuah sistem pengembangan perangkat lunak berbasis Objek (Object Oriented programming). Menurut Nugroho, 2010 Sesungguhnya tidak ada batasan yag tegas diantara berbagai konsep dan konstruksi dalam UML, tetapi untuk menyeder-hanakannya, kita membagi sejumlah besar konsep dan dalam UML menjadi beberapa view. Suatu view sendiri pada dasarnya merupakan sejumlah konstruksi pemodelan UML yang merepresen-tasikan suatu aspek tertentu dari sistem atau perangkat lunak yang sedang kita kembangkan. Pada peringkat paling atas, view-view sesungguhnya dapat dibagi menjadi tiga area utama, yaitu: klasifikasi struktural (structural classification), perilaku dina-mis (dinamic behaviour), serta pengolahan atau manajemen model (model management)

\section{Basis Data (Database)}

Data adalah bahan yang akan diolah, dapat berupa angka, huruf, simbol, atau kata-kata yang menunjukan suatu sistuasi. Sedangkan basis data itu sendiri adalah kumpulan file yang saling terkait dan membentuk hubungan yang mempunyai kaitan satu dengan yang lainnya sehingga membentuk suatu bangunan data yang digunakan untuk menginformasikan suatu perusahan, instalasi, dan organisasi dalam batasan tertentu 


\section{B. LITERATURE REVIEW}

\section{Borland Delphi 7.0}

Borland Delphi 7 merupakan bahasa pemrograman berbasis Windows. Delphi 7 dapat membantu untuk membuat berbagai macam aplikasi yang berjalan di sistem operasi Windows, mulai dari sebuah program sederhana sampai dengan program yang berbasiskan client/server atau jaringan. Delphi, termasuk aplikasi yang dapat digunakan untuk mengolah teks, grafik, angka, database dan aplikasi web Berbasis Object Oriented Programming (OOP). Setiap bagian yang ada pada program dipandang sebagai suatu object yang mempunyai sifat-sifat yang dapat diubah dan diatur.

Satu file .exe. Setelah program dirancang dalam IDE (Intergrated Development Environment) Delphi, Delphi akan mengkompilasinya menjadi sebuah file executable tunggal. Program yang dibuat dapat langsung didistribusikan dan dijalankan pada komputer lain tanpa perlu menyertakan file DLL dari luar.

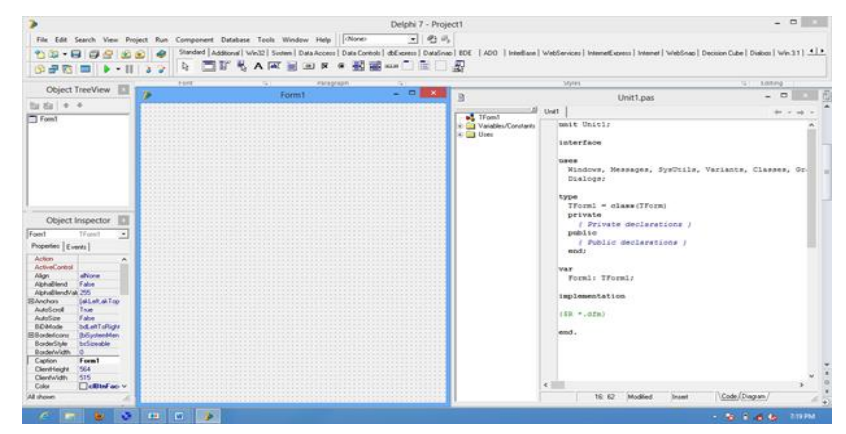

\section{Main Window (Jendela Utama)}

Jendela utama adalah bagian dari IDE yang mempunyai fungsi yang sama dengan semua fungsi utama dari program aplikasi windows lainnya. Jendela utama Delphi terbagi menjadi tiga bagian, yaitu Main Menu, Toolbar, dan Component Palette.

\section{Main Menu (Menu Utama)}

Menu pada Delphi memiliki kegunaan yang sama seperti menu pada aplikasi windows. Dengan menggunakan fasilitas menu, Anda dapat memanggil atau menyimpan program, sehingga pada dasarnya semua perintah yang dikerjakan dapat ditemukan pada bagian menu utama. Nama-nama menu ditampilkan pada bagian menu bar yang terdapat pada bagian atas layar. Untuk bekerja dengan menggunakan menu, dapat menggunakan fasilitas mouse maupun keyboard.

\section{Toolbar}

Delphi memiliki beberapa toolbar yang masing-masing memiliki perbedaan fungsi dan setiap tombol pada bagian toolbar berfungsi untuk menggantikan suatu perintah menu yang sering digunakan. Toolbar terletak pada bagian bawah baris menu. Pada kondisi default, terdapat enam bagian toolbar, antara lain standard, view, debug, desktop, custom dan component palette.

\section{Component palette}

Berisi sekumpulan ikon yang melambangkan komponen-komponen yang terdapat pada VCL (Visual Component Library). Pada component palette terdapat beberapa page control seperti standard, additional, Win32, System, Data Access, dan lain-lain . Untuk Lebih Jelasnya Anda dapat

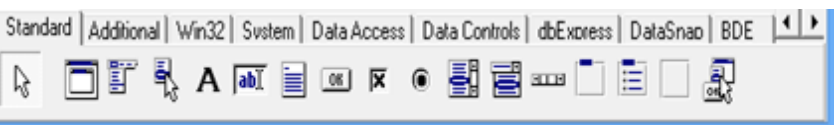

\section{Object Inspector}

Digunakan untuk mengubah properti atau karakteristik dari sebuah komponen, terdiri dari dua tab, yaitu properties dan events.

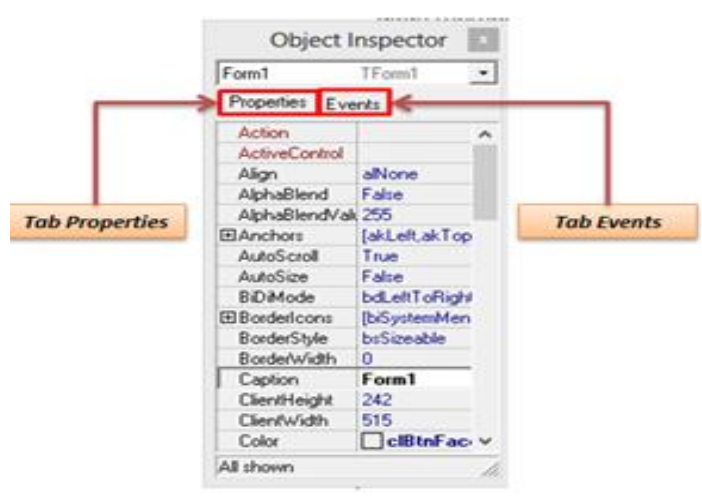


1. Microsoft Acces 2007

Microsoft Acces 2007 adalah salah satu software pengolah database yang berjalan dibawah sistem windows. Microsoft Access merupakan salah satu produk Office dari Microsoft yang dapat menangani database. Dalam pengolahan database, Microsoft Access ini memiliki sarana atau objek-objek yang dapat mempermudah pekerjaan bagi pengguna.
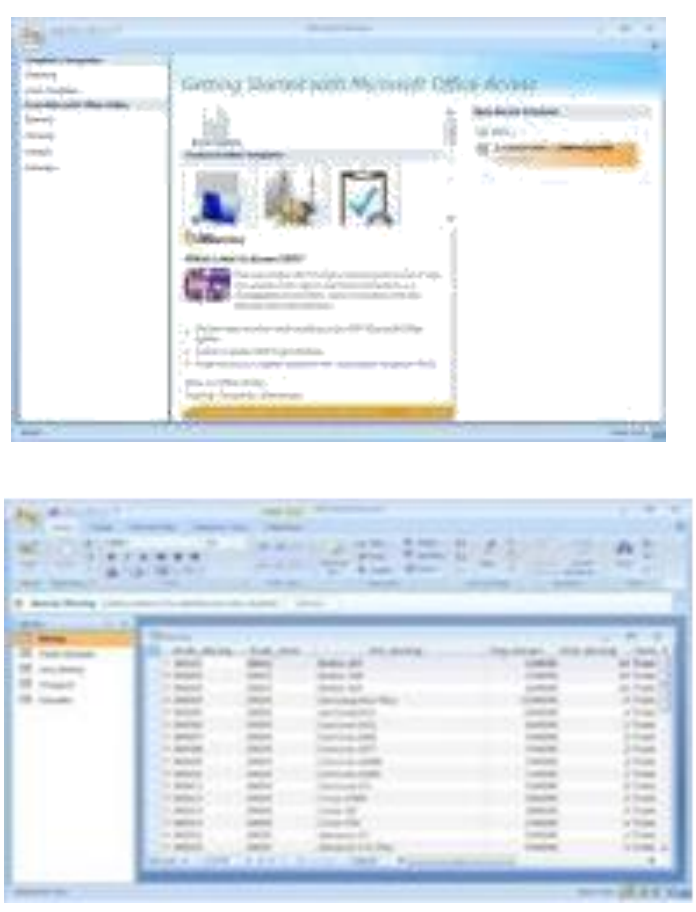

Hal-hal yang berperan penting dalam pembuatan tabel adalah sebagai berikut:

1 Tipe Data

Tipe data digunakan untuk mendefinisikan tipe data yang dimiliki oleh objek server seperti variable, parameter, kolom (field).

2 Relasi Antar Tabel dan Tipe Datanya Untuk memperoleh table yang benar bisa melalui tahapan normalisasi atau pembuatan Entity Relationship Diagram (ERD)

3 Struktur Tabel

Pada struktur tabel terdapat empat coloum yaitu Field, Type (size), Null, dan Keterangan

\section{RESULT}

\section{Flowchart}

Desain model secara umum yang akan dibuat dalam bentuk gambar berupa flowchart, adapun flowchart system dan diagram alur data system informasi penjualan yang diusulkan adalah

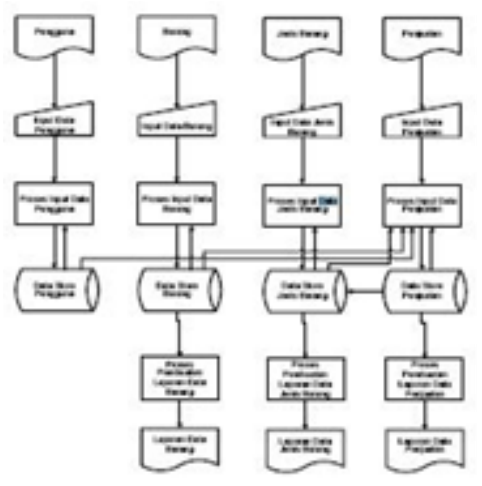

\section{Relasi Antar Tabel}

Adapun relasi antar tabel tersebut adalah sebagai berikut :

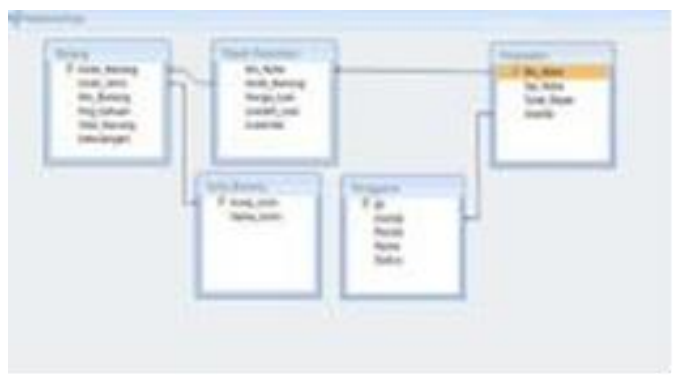

\section{Implementasi Sistem}

Dalam Sistem Informasi Penjualan pada Ade Jaya Ponsel admin mempunyai wewenang penuh dalam hal pengolahan data barang, jenis barang, dan pengguna. Admin juga dapat melakukan pengecekan secara detail informasi mengenai stok barang pada AdeJayaPonsel yang dapat dilihat pada laporan seluruh jenis barang, laporan seluruh barang, laporan seluruh penjualan, laporan penjualan per-nota, dan laporan penjualan per-periode. Hak akses sebagai kasir dibatasi untuk menghindari manipulasi data yang tidak diinginkan, kasir hanya bisa mengakses transaksi penjualan, laporan seluruh jenis barang, dan laporan seluruh barang. 
Sistem

Logout

Untuk memudahkan kasir dan admin untuk logout dan login tanpa harus menutup aplikasi "sistem informasi penjualan pada adejaya ponsel dengan menggunakan visual basic".

\section{CONCLUSION}

\section{Kesimputan}

Aplikasi ini dapat mempermudah frontline dalam pembukuan serta pembuatan laporan dan mempermudah owner mengecek rekap data. Sistem pelaporan dengan menggunakan Visual Basic 6.0 lebih mudah dan efektif dibandingkan menggunakan sistem pelaporan secara manual. Penggunaan aplikasi ini tidak dapat dilakukan oleh sembarang orang karena dilengkapi dengan sistem log in.

\section{E. ACKNOWLEDGEMENT}

University Of Indonesia University Of Mitra Indonesia Telkom University University Of Mellbourne Saitama University

\section{F. REFERENCES}

[1] A. S. Putra, H. Sukri, and K. Zuhri,"SistemMonitoring Realtime Jaringan Irigasi Desa (JIDES)DenganKonsep Jaringan Sensor Nirkabel," IJEIS (Indonesian J. Electron. Instrum. Syst., vol. 8, no. 2, pp. 221-232.

[2] D. P. Sari, O. M. Febriani, and A. S. Putra, "Perancangan Sistem Informasi SDM Berprestasi pada SD Global Surya," in Prosiding Seminar Nasional Darmajaya, 2018, vol. 1, no. 1, pp. 289-294.

[3] A. S. Putra, "Paperplain: Execution Fundamental Create Application With Borland Delphi 7.0 University Of Mitra Indonesia," 2018.
Hartati, "Metode SAW

(Simple

Additive Weighting) sebagai Sistem Pendukung Keputusan Guru Berprestasi (Studi Kasus: SMK Global Surya)," in Prosiding Seminar Nasional Darmajaya, 2018, vol. 1, no. 1, pp. 85-97.

[5] A. S. Putra and O. M. Febriani, "KnowledgeManagement Online Application in PDAM LampungProvince,"in Prosiding International conference on Information Technology and Business (ICITB), 2018, pp. 181-187.

[6] A. S. Putra, O. M. Febriani, and

B. Bachry, "Implementasi Genetic Fuzzy System Untuk Mengidentifikasi Hasil Curian Kendaraan Bermotor Di Polda Lampung," SIMADA (Jurnal

[4] A. S. Putra, D. R. Aryanti, and I. 
Sist. Inf. dan Manaj. Basis Data), vol. 1, no. 1, pp. 21-30, 2018.

[7] A. S. Putra, "2018 Artikel Struktur Data, Audit Dan Jaringan Komputer," 2018.

[8] O. M. Febriani and A. S. Putra, "Sistem Informasi Monitoring Inventori Barang Pada Balai Riset Standardisasi Industri

Bandar Lampung," J. Inform., vol. 13, no. 1, pp. 90-98, 2014. 
$\circlearrowright$ Manual Books Article Task 